\title{
Analysis of propagation models for digital terrestrial television (DTT), under the ISDB-Tb standard in cities of Ambato and Latacunga, Ecuador
}

\section{Análisis de modelos de propagación para televisión digital terrestre (TDT), bajo el estándar ISDB-Tb en las ciudades de Ambato y Latacunga, Ecuador}

\author{
Jairo R. Jácome $e^{1, *}$, Alexandra O. Pazmiño ${ }^{1, \dagger}$, Javier J. Gavilanes ${ }^{1, \ddagger}$, Oswaldo G. Martínez ${ }^{2, \theta}$, \\ and Jefferson A. Ribadeneira ${ }^{2, \sigma}$ \\ ${ }^{1}$ Facultad de Mecánica, Escuela Superior Politécnica de Chimborazo, Riobamba, Ecuador. \\ ${ }^{2}$ Facultad de Informática y Electrónica, Escuela Superior Politécnica de Chimborazo, Riobamba, Ecuador. \\ \{jjacome, apazmino_a,javier.gavilanes,omartinez,jefferson.ribadeneira\}@espoch.edu.ec
}

Received: August 15, 2017 - Accepted: September 15, 2017

\begin{abstract}
How to cite: Jácome, J. R., Pazmiño, A. O., Gavilanes, J. J., Martínez, O. G., \& Ribadeneira, J. A. (2018). Analysis of propagation models for digital terrestrial television (DTT), under the ISDB-Tb standard in cities of Ambato and Latacunga, Ecuador. Journal of Science and Research: Revista Ciencia e Investigación, 3(CITT2017), 84-90. https://doi.org/10.26910/issn.2528-8083vol3issCITT2017.2018pp84-90

Abstract-Most countries in South America have adopted ISDB-Tb as a standard for Digital Terrestrial Television broadcasts. In some countries, the deployment is in the early stages. However, the unique conditions of the South American countries have not taken into account the selection of the propagation model used for the unbundling of new DTT networks. Ecuador has adopted the ISDB-Tb for DTT transitions, which optimizes the radio spectrum and implements new audiovisual and interactive services. At present, DTT signals are being tested in the cities of Ambato and Latacunga. For the successful implementation of DTT in the Andi-nos countries, it is necessary to select the propagation model that best suits the propagation conditions of the region. The present study determines the model of propagation that best adjusts to the conditions of propagation of the cities under study through field measurements. The selection of cities is relevant in the sense that they have geographic and climatological characteristics similar to those of other cities in the Andean region, so the results can be extrapolated to other cities in the region. The model of propagation that best fits the geographic conditions of the region was model ITU-R 525/526.
\end{abstract}

Keywords-Models of propagation, Digital terrestrial television, ISDB-Tb, Field measurements, SACER.

Resumen - El Ecuador adoptó el estándar ISDB-Tb para Televisión Digital Terrestre, el mismo que optimiza el espectro radioeléctrico e implementa nuevos servicios audiovisuales e interactivos. Se realizan emisiones de pruebas de las señales de TDT en las ciudades Ambato y Latacunga, para la exitosa implementación de la TDT hay que seleccionar el modelo de propagación que se ajusta a las condiciones geográficas y topográficas de las ciudades. El presente trabajo determinó el modelo de propagación para la Televisión Digital Terrestre bajo el estándar ISDB-Tb que mejor se ajustó a las condiciones de las ciudades de Ambato y Latacunga, debido a que las mismas tienen características similares de la región andina y los resultados obtenidos pueden ser extrapolados a las demás ciudades de la región. La investigación es cuantitativa, debido a que se examinó numéricamente los datos tomados de los canales de Televisión Digital Terrestre como son longitud, latitud y potencia. El modelo de propagación que mejor se ajustó a las condiciones geográficas de los sectores es el ITU-R 525/526 y se recomienda extender el análisis realizado en el presente tema de titulación para las demás ciudades y provincias del Ecuador, además se realizó el análisis comparativo de las medidas que fueron tomadas con las medidas simuladas, éste análisis permitió determinar qué modelo se ajustó a lo requerido.

Palabras Clave-Modelos de Propagación, Televisión Digital Terrestre, Norma ISDB-tb, Espectro Radioeléctrico, SACER.

\section{INTRODUCTION}

$\mathbf{T}$ elecommunications are important for the economic and social ties of the country. Television is a prominent medium that centralizes much of the information that comes to homes at any time and with different schedules. Particularly the open television, being a service of the telecommunications uses the radioelectric spectrum as indicated in the Constitution

\footnotetext{
* Magister en Sistemas de Telecomunicaciones.

${ }^{\dagger}$ Magíster en Informática Empresarial

${ }^{\ddagger}$ Máster en Automática y Robótica

${ }^{\theta}$ Master Universitario en Sitemas Tecnologias y Redes de Comunicaciones

$\sigma$ Doctor en Telecomunicación
}

of the Republic of Ecuador article 261, numeral 10 (CONSTITUCION DEL ECUADOR, 2008).

With the announced analogue blackout of television in Ecuador, the existing technological gap will be removed and at the forefront of technological advances. The present study analyzes the existing propagation models for DTT in the cities of Latacunga and Ambato. Real data are taken from rural and urban areas to help determine the propagation model that best fits the two cities. The results can be extrapolated to the cities of the Andean region due to the similarity of their topographic and climatological conditions. 


\section{Problematic Situation}

According to the Ministry of Telecommunications, on March 26, 2010, the ISDB-Tb standard for DTT was officially adopted, this process allows the optimization of the radio spectrum and implementation of new services, currently the television channels are analogue, which does not allow a good distribution of radio spectrum. In the country DTT tests are carried out in the cities of: Quito, Guayaquil, Cuenca, Ambato, Latacunga, among others (Ministerio de Telecomunicaciones, $2015 b$ ). For a successful implementation of DTT, it is necessary to plan the networks and it is important to select the propagation model; The most used are the ITU-R 1546 which is semi-deterministic and is based on measurements made in the United States and Europe. Currently there is no model of propagation that is in tune with measures carried out in Ecuador because of this the existing models may not fit adequately to the geographical environment of the country. The choice of an inadequate propagation model causes that the planning of coverage of DTT networks is wrong, because there may be neighboring transmitters that are interfered with by transmitters with a greater range than planned.

\section{Digital Terrestrial Television}

The image and sound in DTT are converted digital format that are transmitted by electromagnetic waves, transmitting digital information gives us mobility, quality and optimization of the electromagnetic spectrum; It is also possible to broadcast several programs in HD, standard quality and interactivity. The DTT standards worldwide are four: ATSC (ATSC, 2007), DVB-T (European Standard, 2014), ISDB-T (Broadcasting, 2001) and DTMB (Ong, 2009); In addition, there is the ISDB$\mathrm{Tb}$, which is a modification of the Japanese standard developed in Brazil (Alulema, 2012). DVB-T2 (Etsi, 2012) is the second generation of the DVB and ATSC 3.0 family of standards (Fay et al., 2016) in the process of standardization. In North America the standard used is ATSC, which is characterized by its high definition and good sound quality digital dolby type. In Japan, ISDB-T characterized by portability and mobility. In China, DTMB offers high definition, mobility and portability, and in Europe the DVB-T characterized by its interactivity. In some of the countries of Latin America, a variant of the ISDB-T developed by Brazil is called ISDB-Tb (Ribadeneira Ramírez, 2016). At the moment South America with the exception of Colombia, Guyana, Suriname and French Guiana have adopted ISDB-Tb, it should be noted that ISDB-Tb has been designed to be applied to 6,7 and $8 \mathrm{MHz}$ bandwidth channels, with the $6 \mathrm{MHz}$ channel for two reasons: Because it is the channeling used exclusively in the region and because it will be easier to understand all the numerical relationships that govern the system (Pisciotta, 2010). In Ecuador, $6 \mathrm{MHz}$ channels are used as the channel used in America. ISDB-Tb within its main feature has narrow band reception called partial because it uses only a bandwidth, the fourteenth part to be precise. Partial reception has important advantages, including simpler receiver circuitry compared to equipment of the same size capable of processing the full bandwidth of the signal and also involves the division of the channel into portions, called segments by the ISDB standard -Tb; For this reason the system is also known as OFDM-segmented band (Pisciotta, 2010).

\section{Digital Terrestrial TeleVision in ECUAdor}

The transition to DTT is a State policy that promotes access to new information and communication technologies to incorporate the population into the knowledge society and the productive sphere. Through Resolution No. 084-05-CONATEL-2010 of March 25, 2010 (Ministerio de Telecomunicaciones, 2015a), the country adopts the ISDB-Tb standard for the implementation of DTT, with $47 \%$ of Ecuadorians who have considered buying a TV set standard. Within the market concentration of private operators, 10 concessionaires concentrate $70 \%$ of the private open TV stations and within the current DTT coverage and indicates that $34.85 \%$ of the population already has coverage. In addition, within the country's master plan for DTT is contemplated the analog blackout in 3 phases; Phase 1 includes stations that cover at least one provincial capital, cantonal headland or parish with a population greater than 500,000, which ended on December 31, 2016. Phase 2 includes stations that cover at least one capital province, cantonal head or parish with population between 500,000 and 200,000 inhabitants, which will end on December 31, 2017 and phase 3 comprises stations that at least cover a provincial capital, cantonal head or parish with a population of less than 200,000 inhabitants, this phase will end on December 31, 2018. The application of DTT to the productive sphere will be reflected in research and development, industry, training and services provided by technology (Ministerio de Telecomunicaciones, 2015a).

\section{Models of Propagation}

A propagation model is able to predict the trajectory loss of a radio frequency signal between the base station and the receiver. These models are the collection of mathematical expressions, diagrams and algorithms that symbolize the characteristics of the signals in relation to the noise and the different sources of interference that may arise. The models of propagation are classified in: Statistical, empirical, deterministic or theoretical, including combinations. Empiricals base their predictions on actual measurements unlike theorists who use the fundamental principles of an RF wave propagation. The applicability of a model depends on certain factors, such as terrain type, conductivity of the earth, atmospheric characteristics, urban constructions, etc (Gandia et al., 2011).

\section{Models of DTT Propagation applicable in rural and urban areas}

For prediction of propagation losses in rural areas, there are methods ITU-R 525/526 (International Telecomunications Union, 2016) and ITU-R 1546 (ITU-R, 2009). For its application, the propagation model is chosen and correction factors are used, specifying factors adapted to each type of zone, and for urban zones, empirical and semi-deterministic models are used. The advantage is that they are formulated with closed equations that depend on few parameters and are easy to calculate. In urban areas the models that best fit the frequency 
range in which DTT networks are deployed in South America are: Okumura-Hata (Hata, 1980), Xia-Bertoni (Maciel et al., 1993), Hata + Deygout Hata (Deygout, 1966).

\section{SAMPLE Size}

Samples were taken through cities each 100 square meters, the area of the city of Ambato is $46.50 \mathrm{~km}^{2}$ and the Latacunga of $264.86 \mathrm{~km}^{2}$ (INEC, 2016). We obtain the sample for the development of the work with the following formula:

$$
n=\frac{N \sigma^{2} Z^{2}}{(N-1) e^{2}+\sigma^{2} Z^{2}}
$$

Where:

$\mathrm{n}=$ The size of the sample.

$\mathrm{N}=$ Population size.

$\sigma=$ Standard deviation of the population (0.5).

$\mathrm{Z}=$ Value obtained through confidence levels. (1.96) relative to the $95 \%$ confidence level.

$\mathrm{e}=$ Acceptable sample error limit (0.05) corresponding to $1 \%$.

For Ambato and Latacunga for each $1 \mathrm{~km}^{2}$ we will have 10 samples, in the case of Ambato $\mathrm{N}$ is 465 samples and applying the formula gives us the following:

- $n=375$; Size of the sample for Ambato and 7315 samples were obtained.

- $\mathrm{n}=378$; Size of the sample for Latacunga and 1734 samples were obtained.

For the operation monitoring of DTT stations, the SACER SCT-101 (Automatic Radio Spectrum Control System) station was used as shown in Figure 1. The station performs measurements of the electric field strength level, bandwidth, DriveTest, occupation and coverage in the main cities of Ecuador.

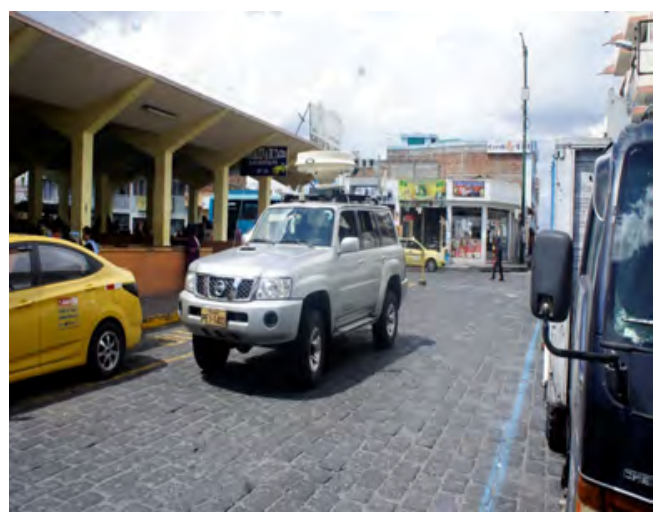

Figure 1. Station SACER sct-101, with which the acquisition was made of samples in the cities of Ambato and Latacunga.

Source: Prepared by the authors.

The speed of the route was $25 \mathrm{~km} / \mathrm{h}$, which guaranteed the acquisition of the samples and the ARGUS software allowed the configuration of the measurement parameters in the station, the station equipment are shown in Figure 2.

The samples were obtained from the Color TV channel, due to the fact that by means of Official No. ARCOTEL-CZ032017-0001-OF indicates that the UNIMAX Television Channel serving the city of Ambato is not in operation. Table 1 shows
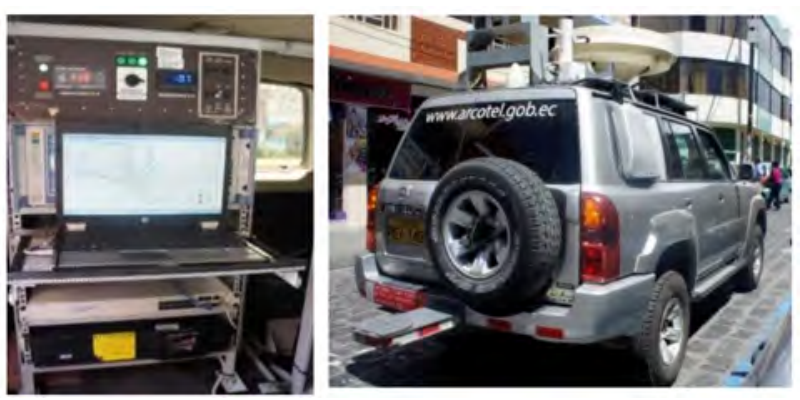

Figure 2. Station SACER sct-101, with which the acquisition was made of samples in the cities of Ambato and Latacunga.

Source: Prepared by the authors.

the characteristics of the transmission antenna of the Color TV channel.

Table 1. Technical characteristics of the transmission antenna of Color Tv.

\begin{tabular}{|l|c|}
\hline \multicolumn{2}{|c|}{ Technical characteristics of the transmission antenna of Color Tv } \\
\hline Antenna transmission power & $400 \mathrm{~W}$ \\
\hline Tower height & 48 meters \\
\hline Antenna make and model & Make OMB Model PD2000 \\
\hline Array array azimuth & $\begin{array}{c}4 \text { antennas with azimuth towards } \\
\text { the city of Ambato. } \\
5 \text { antennas with azimuth towards } \\
\text { the city of Latacunga. }\end{array}$ \\
\hline Total antenna array gain & $22 \mathrm{dbi}$ \\
\hline $\begin{array}{l}\text { Gain of the antenna of } \\
\text { reception of the station Sacer }\end{array}$ & $16 \mathrm{dbi}$ \\
\hline
\end{tabular}

Source: Prepared by the authors.

The transmission antenna of the television channel is located in Pilisurco hill, its location is shown in Table 2 and is in the province of Tungurahua; Due to its geographical location, many of the local, regional and national television stations have been located, as shown in Figure 3.

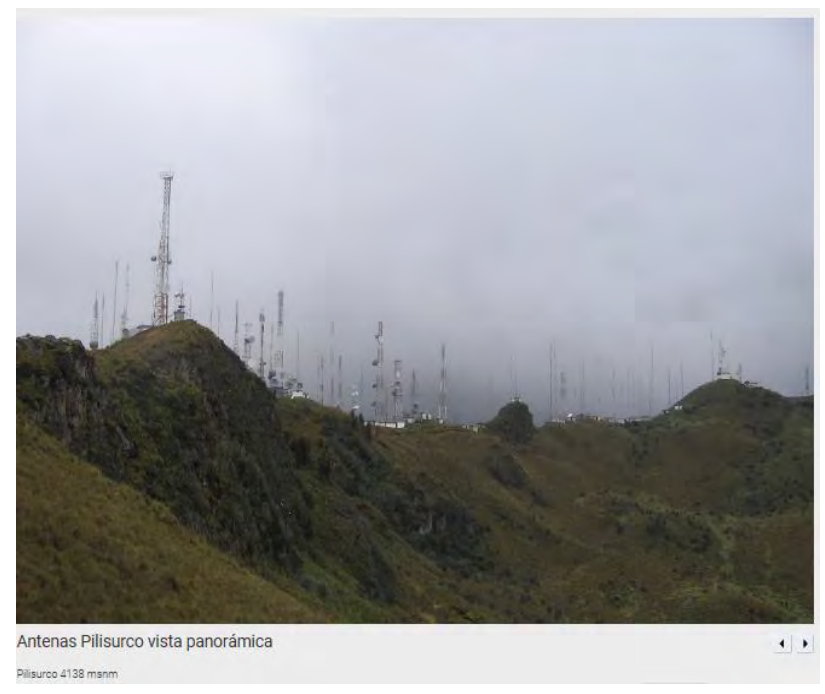

Figure 3. Panoramic view of the TV antennas in Pilisurco hill.

Source: Prepared by the authors.

They were concluded on December 12, 2016 for Ambato and December 19 for Latacunga, the frequency of operation 
Table 2. Technical characteristics of the transmission antenna of Color Tv.

\begin{tabular}{|l|c|}
\hline $\begin{array}{c}\text { LOCATION OF THE COLOR TV CHANNEL } \\
\text { TRANSMISSION ANTENNA }\end{array}$ \\
\hline Latitude & $1^{\circ} 09^{\prime} 21,2^{\prime \prime} \mathrm{S}$ \\
\hline Length & $78^{\circ} 39^{\prime} 51,9^{\prime \prime} \mathrm{W}$ \\
\hline Height above sea levell & $4138 \mathrm{msnm}$ \\
\hline
\end{tabular}

Source: Prepared by the authors.

of the Color Tv Channel transmitter is in the band between $536 \mathrm{MHz}$ to $542 \mathrm{MHz}$, of those $6 \mathrm{MHz}$ of $\mathrm{AB}$ was taken channel center frequency for the $539 \mathrm{MHz}$ analysis, as shown in Figure 4.
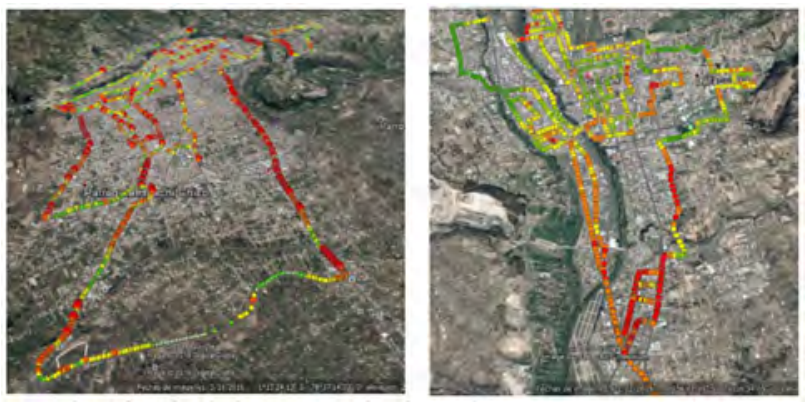

Figure 4. Sampling in the urban area of Ambato and Latacunga.

Source: Prepared by the authors.

In Figure 5, the results obtained from the Drive Test for the frequency of $539 \mathrm{MHZ}$ for the city of Ambato can be observed.

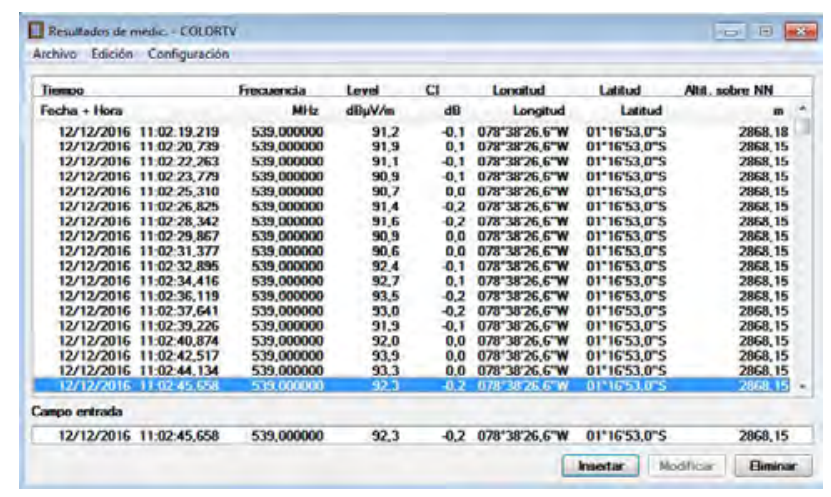

Figure 5. Samples taken at the $539 \mathrm{MHz}$ frequency for Ambato.

Source: Prepared by the authors.

\section{RESUlTS AND DISCUSSION}

The results obtained from the Drive Test we can confirm that the spectrum of the Color TV Television Channel for the two cities is $6 \mathrm{MHz}$ of bandwidth. As shown in Figure 6.

It was verified that the Color Tv channel is transmitting OFDM signal and for the realization of the simulations professional planning software was used, which is based on a cartographic information system and also allows to make simulations and representations of the most deployed radiocommunication systems in the medium with the possibility to calculating the performance of the systems with the high
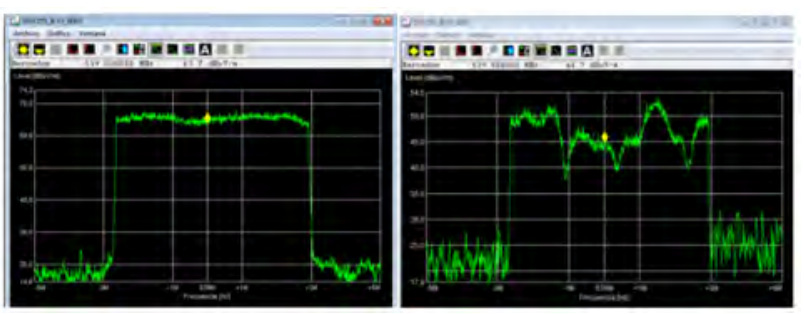

Figure 6. Samples taken at the $539 \mathrm{MHz}$ frequency for Ambato.

Source: Prepared by the authors.

precision. The models ITU-R 525, ITU-R 525/526 and the ITU-R 1546 are the models studied for the case. All these models work in the UHF band.

\section{Correlation analysis of the field measurements in the city of Latacunga}

\section{ITU-R 525.}

For the case of ITU-R P.525, three types of diffraction, Deygout 94, Rounded Form and Cylinder Form were analyzed, each with two methods of subtraction ITU-R 526 and fine integration. In Figure 7, the obtained graph result is observed and in Table 3 the numerical results for the model and their combinations.

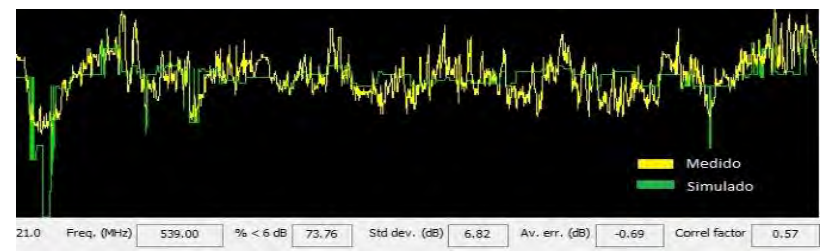

Figure 7. Correlation between propagation model ITU-R P.525 with diffraction Shape Rounded and field measurements.

Source: Prepared by the authors.

\section{ITU-R 525/526.}

For the propagation model ITU-R P.525/526 we used the diffraction types and subroutine methods as the ITU-R525 model as shown in Figure 8.

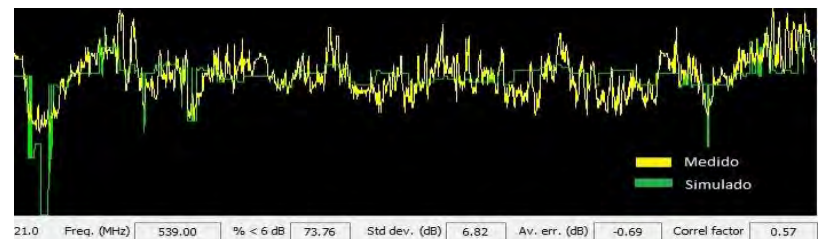

Figure 8. Correlation between propagation model ITU-R P.525/526 with diffraction Shape Rounded and field measurements.

Source: Prepared by the authors.

\section{ITU-R 1546.}

It is a semi-deterministic model that is based mainly on field measurements with correction factors and that takes attenuations by diffraction and by subtraction. In Figure 9, the simulation is observed. 


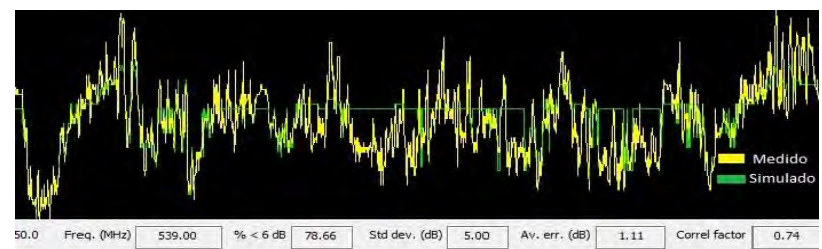

Figure 9. Correlation between propagation model ITU-R P.1546 without diffraction and field measurements.

Source: Prepared by the authors.

\section{Correlation analysis of the field measurements in the city of Ambato}

\section{ITU-R 525.}

In the case of ITU-R P.525 three types of diffraction, Deygout 94, Rounded Form and Cylinder Form were analyzed, each with two methods of subroutine that in this case were the ITU-R 526 subroutine and the subroutine of Integration fine. In Figure 10, the graphic results obtained were observed.

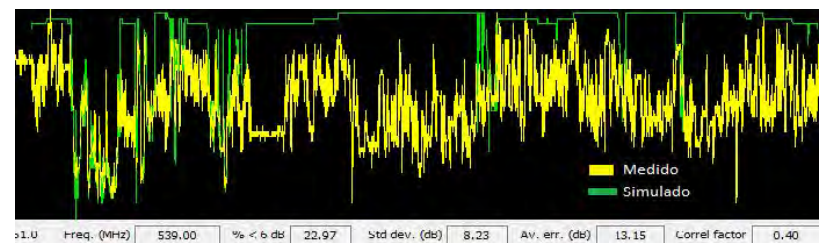

Figure 10. Correlation between ITU-R propagation model P.525 with Deygout94 diffraction and field measurements.

Source: Prepared by the authors.

\section{ITU-R 525/526.}

For the propagation model ITU-R P.525/526 the diffraction types and subroutine methods were used as the ITU-R525 model as shown in Figure 11.

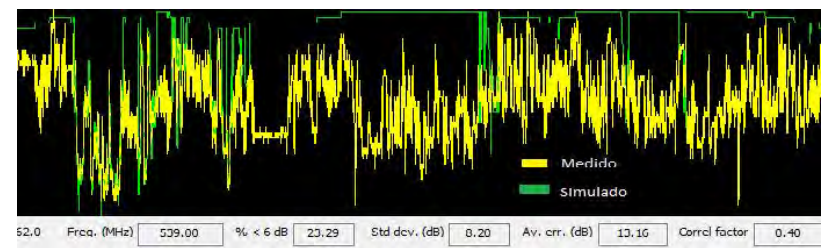

Figure 11. Correlation between propagation model ITU-R P.525/526 with diffraction Shape Rounded and field measurements.

Source: Prepared by the authors.

\section{ITU-R 1546.}

Figure 12 shows the simulations performed for this propagation model.

\section{Proposal}

We will cite Table 3 for the city of Latacunga, where we observe the results of the simulations with the measurements taken and the simulated ones. The proposed propagation model is ITU-R 525/526, because its correlation factor is 0.67 and approaches 1 which is the ideal value. The model of

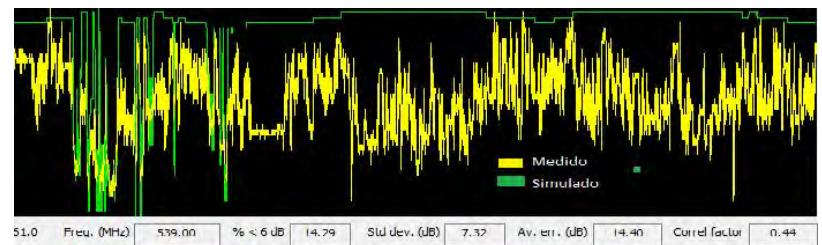

Figure 12. Correlation between propagation model ITU-R P.1546 without diffraction and field measurements.

Source: Prepared by the authors.

propagation ITU-R 1546 with $50 \%$ location and $1 \%$ time is the one that for the city of Latacunga has a correlation factor of 0.74 that could be considered better than the correlation factor of the model 525/526, however these cases are special because the scenario with these conditions are very particular and is likely not to be in real life.

For Ambato we will quote Table 4 and the proposed propagation model is ITU-R 525/526, because its correlation factor is 0.40 and approaches 1 which is the ideal value.

The ITU-R 1546 propagation model with $50 \%$ location and $1 \%$ time for the city of Latacunga has a correlation factor of 0.44 that can be considered to be better than the correlation factor of the model 525/526, however this case is special because the scenario with those conditions are very particular.

\section{COnClusions}

For the network planning for the cities of Ambato and Latacunga where their geographical area is very similar because they are not very distant from each other and because in the central region of Ecuador the model of propagation that best fits the Conditions is ITU-R 525/526.

The conditions of DTT propagation for television channels operating in the cities of Latacunga and Ambato are similar, because each city has buildings that are concentrated in the cantonal head of the city and is where the signal arrives with less power than in the peripheral areas where the scenario is the opposite.

Using the right propagation model will save TV operators, work, time and money.

To determine the model of propagation for DTT in the two cities, it was essential to carry out the comparative analysis of the measurement that were taken with the simulated measures, this analysis allowed to determine which model fits the requirement.

\section{RECOMMENDATIONS}

Take measurements of Digital Terrestrial Television channels for the cities and provinces of the central region that are missing, and for the provinces of the Insular, coastal and eastern regions.

Extend the analysis carried out in the present title theme for the other cities and provinces of Ecuador.

Properly characterize the antennas and carry out the detailed studies, prior to the start of operations of the DTT transmitters. 
Table 3. Summary of Results of Propagation Models and their Diffraction and Subpath Models in the city of Latacunga.

\begin{tabular}{|l|l|l|c|c|}
\hline \multicolumn{1}{|c|}{$\begin{array}{c}\text { Propagation } \\
\text { model }\end{array}$} & $\begin{array}{c}\text { Diffraction } \\
\text { model }\end{array}$ & $\begin{array}{c}\text { Subroutine } \\
\text { Model }\end{array}$ & $\begin{array}{c}\text { Correlation } \\
\text { Factor }\end{array}$ & $\begin{array}{c}\text { Standard } \\
\text { deviation (dB) }\end{array}$ \\
\hline \multirow{2}{*}{ ITU-R 525 } & Deygout94 & Fine integration & 0.67 & 5.54 \\
\cline { 2 - 5 } & Round shape & Fine integration & 0.57 & 6.82 \\
\cline { 2 - 5 } Cylinders & Fine integration & 0.67 & 5.57 \\
\hline \multirow{2}{\text{ITU-R525/526}}{} & Deygout94 & Fine integration & 0.67 & 5.54 \\
\cline { 2 - 5 } & Round shape & Fine integration & 0.57 & 6.82 \\
\cline { 2 - 5 } $\begin{array}{l}\text { ITU-R 1546 } \\
\text { Cocation 50\% } \\
\text { Time 1\% }\end{array}$ & $\begin{array}{c}\text { Without } \\
\text { diffraction }\end{array}$ & Fine integration & 0.67 & 5.57 \\
\hline $\begin{array}{l}\text { ITU-R 1546 } \\
\text { Location 50\% } \\
\text { Time 50\% }\end{array}$ & $\begin{array}{c}\text { Without } \\
\text { diffraction }\end{array}$ & No loss & 0.74 & 5 \\
\hline
\end{tabular}

Source: Prepared by the authors.

Table 4. Summary of Results of Propagation Models and their Diffraction and Subpath Models in the city of Latacunga.

\begin{tabular}{|l|l|l|c|c|}
\hline \multicolumn{1}{|c|}{$\begin{array}{c}\text { Propagation } \\
\text { model }\end{array}$} & $\begin{array}{c}\text { Diffraction } \\
\text { model }\end{array}$ & $\begin{array}{c}\text { Subroutine } \\
\text { Model }\end{array}$ & $\begin{array}{c}\text { Correlation } \\
\text { Factor }\end{array}$ & $\begin{array}{c}\text { Standard } \\
\text { deviation (dB) }\end{array}$ \\
\hline \multirow{3}{*}{ ITU-R 525 } & Deygout94 & ITU-R 526 & 0.40 & 8.23 \\
\cline { 2 - 5 } & Round shape & ITU-R 526 & 0.40 & 8.20 \\
\cline { 2 - 5 } & Cylinders & ITU-R 526 & 0.40 & 8.27 \\
\hline \multirow{2}{*}{ ITU-R 525/526 } & Deygout94 & ITU-R 526 & 0.40 & 8.23 \\
\cline { 2 - 5 } & Round shape & ITU-R 526 & 0.40 & 8.20 \\
\cline { 2 - 5 } $\begin{array}{l}\text { Cylinders } \\
\begin{array}{l}\text { Location 50\% } \\
\text { Time 1\% }\end{array}\end{array}$ & $\begin{array}{c}\text { Without } \\
\text { diffraction }\end{array}$ & No loss & 0.40 & 7.32 \\
\hline $\begin{array}{l}\text { ITU-R 1546 } \\
\text { Location 50\% } \\
\text { Time 50\% }\end{array}$ & $\begin{array}{c}\text { Without } \\
\text { diffraction }\end{array}$ & No loss & 0.37 & 8.27 \\
\hline
\end{tabular}

Source: Prepared by the authors.

\section{FUTURE WORK}

The present research work is the beginning of some works that will be developed in the future, taking into account the geography of the regions that Ecuador has, the models of propagation will be analyzed for each of them, as well as the analysis between rural and urban areas of other provinces.

\section{BIbLIOGRAPHIC REFERENCES}

Alulema, D. (2012). La televisión digital terrestre en el ecuador es interactiva. Eidos, (5):12-19.

ATSC (2007). A / 53: ATSC Digital Television Standard, Parts 1 - 6. ATSC Standard, (01):1-136.

Broadcasting, T. S. (2001). ARIB STD - B31 TRANSMISSION SYSTEM FOR DIGITAL TERRESTRIAL TELEVISION BROADCASTING Association of Radio Industries and Businesses.

CONSTITUCION DEL ECUADOR (2008). Constitución del Ecuador - 2008. Registro Oficial, 449(Principios de la participación Art.):67.

Deygout, J. (1966). Multiple knife-edge diffraction of microwaves. IEEE Transactions on Antennas and Propagation, 14(4):480-489.

Etsi (2012). ETSI EN 302755 Digital Video Broadcasting (DVB) Frame structure channel coding and modulation for a second generation digital terrestrial television broadcasting system (DVB-T2). Specification for Service Information (SI) in $D V B \ldots, 1: 1-188$.
European Standard (2014). Digital Video Broadcasting (DVB); Framing structure, channel coding and modulation for digital terrestrial television (DVB-T). Igarss 2014, (1):1-5.

Fay, L., Michael, L., Gómez-Barquero, D., Ammar, N., and Caldwell, M. W. (2016). An overview of the atsc 3.0 physical layer specification. IEEE Transactions on Broadcasting, 62(1):159-171.

Gandia, J. J. G., Sánchez, J. L., Barquero, D. G., and Marcet, N. C. (2011). Modelos de propagación radio para redes de tdt móvil en la banda uhf. In Systems \& Telematics (Sistemas y Telemática), volume 9, pages 9-27. Universidad Icesi.

Hata, M. (1980). Empirical formula for propagation loss in land mobile radio services. IEEE transactions on Vehicular Technology, 29(3):317-325.

INEC (2016). Instituto Nacional de Estadística y Censos.

International Telecomunications Union (2016). P.525 : Calculation of free-space attenuation.

ITU-R (2009). Métodos de predicción de punto a zona para servicios terrenales en la gama de frecuencias de 30 a 3000 MHz. Recommendation ITU-R, P.1546-5.

Maciel, L. R., Bertoni, H. L., and Xia, H. (1993). Unified approach to prediction of propagation over buildings for all ranges of base station antenna height. IEEE transactions on vehicular technology, 42(1):41-45.

Ministerio de Telecomunicaciones (2015a). Proceso de Implementación de la Televisión Digital en el Ecuador.

Ministerio de Telecomunicaciones (2015b). Televisión Digital Terrestre en el Ecuador - Ministerio de Telecomunicacio- 
nes y Sociedad de la Información. pages 6-8.

Ong, C.-y. (2009). White paper on latest development of digital terrestrial multimedia broadcasting (dtmb) technologies. Hong Kong Applied Science and Technology Research Institute (ASTRI), Hong Kong.

Pisciotta, N. O. (2010). Sistema isdb-tb. Centro de Investigación Aplicada y Desarrollo en Informatica y Telecomunicaciones (CLADE-IT), pages 4-30.

Ribadeneira Ramírez, J. A. (2016). Planificación de Frecuencias para Televisión Digital Terrestre (TDT) en Sudamérica. $\mathrm{PhD}$ thesis, Universitat Politècnica de València. 